\title{
The effect of post-injury erythropoietin administration on mortality and Glasgow outcome scales of patients with traumatic brain injury: A meta- analysis.
}

\author{
Faye B Garciano*1, Perry N Noble ${ }^{1}$ \\ Department of Neurology, University of the Philippines, Philippines
}

\begin{abstract}
Objectives: To determine whether post-injury treatment with erythropoietin provides lower mortality rates and improved Glasgow Outcome Scales in patients with traumatic brain injury (TBI).

Methods: Randomized controlled trials (RCTs) were searched through PUBMED, Cochrane Central Register of Controlled Trials (CENTRAL), MEDLINE, and www.googlescholar.com. The reference list of a systematic review was also searched.

Results: Four RCTs comparing erythropoietin and placebo, regardless of dose, dosing regimen, and route of administration were reviewed. Data analysis showed that mortality rates for the erythropoietin group (OR $0.63, \mathrm{CI} 0.43,0.93$ ) was significantly lower compared to the placebo group. However, there was no significant difference in the Glasgow Outcome Scales of TBI patients given erythropoietin compared to placebo.

Conclusion: Post-injury treatment with erythropoietin, regardless of dose, dosing regimen, and route of administration yielded lower mortality rates in patients with traumatic brain injury but had no significant effect on Glasgow Outcome Scales. It is recommended that further large scale randomized controlled trials be performed in order to fully establish the safety and support the efficacy of erythropoietin administration in patients with traumatic brain injury.
\end{abstract}

Keywords: Erythropoietin, EPO, Traumatic brain injury, Brain injury.

Accepted on July 05, 2017

\section{Introduction}

Traumatic brain injury (TBI) is defined as altered brain function caused by external trauma [1,2]. Approximately 10 million people worldwide are diagnosed yearly with TBI and the burden of disease is particularly evident in countries with low to middle income [3]. In the Philippines, local data is sparse regarding the incidence of TBI although accidents or injuries are said to be the $4^{\text {th }}$ leading cause of mortality for all ages. In a local study by Consunji et al. regarding mortality patterns in trauma patients in the country's pioneer trauma center, a central nervous system cause of death was ranked as the $3^{\text {rd }}$ most common antecedent cause of death, with direct consequences of TBI and hypoxic encephalopathy [4].

TBI encompasses varying degrees of contusion, diffuse axonal injury, hemorrhage, and hypoxia, with consequent biochemical, metabolic, and cellular alterations leading to progressive tissue damage and cell death. Neurologic deficits can arise from TBI and are usually caused by primary and secondary injury mechanisms. Primary injury is said to involve damage to neurons, axons, glia, and blood vessels occurring at the initial time of trauma. On the other hand, secondary injury develops over time, from minutes to days or even months following trauma. This involves biochemical events such as disturbances in ionic homeostasis, depolarization, neurotransmitter release, lipid degradation, mitochondrial dysfunction, and activation of inflammatory and immune processes, which may potentially be reversible $[5,6]$. The delayed nature of these secondary injury mechanisms provides a window for therapeutic intervention to prevent progression of tissue damage and for improved outcome [5].

In various experimental models of TBI, several pharmacologic agents are said to provide neuroprotection and improve outcome. These include statins, progesterone, cyclosporine A [5], and erythropoietin (EPO) [7]. Erythropoietin has been proven to be an effective and safe treatment for anemia caused by renal failure [8]. However, recent studies have shown that EPO plays a role beyond erythropoiesis in the bone marrow [8,9] EPO has been shown to have a beneficial effect in animal models of TBI by reducing lesion volume and improving neurobehavioral outcomes [10]. This present study has shown that EPO is also clinically useful in the treatment of patients with TBI since the results have shown that patients treated with EPO have lower mortality rates compared to those given placebo.

Erythropoietin is a 34-kDa glycoprotein and is a member of the type I cytokine superfamily. EPO is mainly found in peritubular fibroblasts of the kidney and hepatocytes although EPO is also present in other parts of the body, including endothelial cells, reproductive organs, heart, gastrointestinal tract, muscle cells, and the central nervous system (CNS). In the brain, the 
Citation: Garciano FB, Noble PN. The effect of post-injury erythropoietin administration on mortality and Glasgow outcome scales of patients with traumatic brain injury: A meta-analysis. J Neurol Neurorehabil Res. 2017;2(2):6-9.

expression of EPO is induced by hypoxia and is regulated by hypoxia-induced transcription factor (HIF) [7,9].

Erythropoietin is said to exert its neuroprotective effects following ischemic, hypoxic, metabolic, neurotoxic, and excitotoxic injury. Studies have shown that in the CNS, EPO acts by limiting the production of glutamate and reactive oxygen species, modulating neurotransmission, reversing vasospasm, promoting angiogenesis, preventing apoptosis, and reducing inflammation and recruitment of stem cells [7]. Although a meta-analysis has been done regarding the efficacy of EPO in the treatment of experimental models of TBI [10], as of this writing, there has been no meta-analysis regarding the clinical use of EPO in patients with TBI.

\section{Aim of the study}

The objective of this study is to determine whether post-injury treatment with erythropoietin provides lower mortality rates and improved Glasgow Outcome Scales (GOS) in patients with traumatic brain injury.

\section{Methodology}

\section{Criteria for inclusion of studies}

Types of studies: This meta-analysis included all published randomized controlled trials comparing post-injury administration of erythropoietin and placebo in human subjects with traumatic brain injury.

Types of participants: Randomized controlled studies with patients who met the following criteria were included: human subjects with head trauma, a Glasgow Coma Scale (GCS) of less than 15, and who had no severe pre-existing disease.

Types of interventions: This meta-analysis included randomized controlled trials that evaluated post-injury administration of erythropoietin compared to placebo. EPO must have been given after injury was acquired, regardless of dose, route of administration, and duration of treatment.

Types of outcome measures: The primary outcomes were:

(1) Mortality rate.

(2) Glasgow Outcome Scale.

This is the most widely used outcome measure following traumatic brain injury. It rates patient status into one of five categories: 1 - Dead, 2 - Vegetative State, 3 - Severe Disability, 4 - Moderate Disability, and 5 - Good Recovery [10,11].

Search methods for identification of studies: The following search engines were used to identify studies for inclusion in this meta-analysis: PUBMED, Cochrane Central Register of Controlled Trials (CENTRAL), MEDLINE, and www. googlescholar.com. No language restriction was imposed. The search terms included ['erythropoietin,' or 'EPO'] and ['traumatic brain injury,' or 'traumatic' and 'brain' and injury']. Medical subject heading (MeSH) and free text searches were done. The reference list of a systematic review was also searched.

\section{Data collection and analysis}

\section{Study selection}

Initial screening was done by reviewing the abstracts of the studies that were retrieved from the literature search. The full texts of the studies that met the inclusion criteria, as stated above, were then retrieved, examined, and reviewed.

\section{Data extraction}

From each study, the following data were extracted and subsequently tabulated: author, year of publication, inclusion and exclusion criteria, interventions, and primary and secondary outcomes.

\section{Data analysis}

Review Manager software version 5 was used to analyze statistical data. The forest plot was used to summarize the outcome for the studies involved. The test for homogeneity between studies was measured using the $\mathrm{I}^{2}$ test for heterogeneity.

\section{Results}

Table 1 summarizes the characteristics and data of the studies that met the inclusion criteria. Literature search revealed that there were seven studies on human subjects regarding the use of erythropoietin in TBI. However, one of these studies was excluded because the intervention used was a synthetic form of EPO, specifically darbepoetin alfa [12]. Another study was excluded because the interventions used were either darbepoeitin or EPO and this study was also consequently a case control study [8]. The third study excluded had different outcome measures, which were serum S-100B and Neuron Specific Enolase levels [13]. Table 2 summarizes the outcomes of the four studies included in this meta-analysis. All four studies included in this meta-analysis showed that baseline demographics did not significantly differ among treatment groups and placebo.

Figure 1 shows that there was no significant difference in the Glasgow Outcome Scales of TBI patients given erythropoietin compared to placebo. The three studies were also not homogenous, with an I 2 of $98 \%$. The study by Nichol et al. was not included in this analysis since they used the Extended Version of the Glasgow Outcome Scale (GOS-E) [14]. This extended version categorizes TBI into eight categories, namely: 1 - Death, 2 - Vegetative state, 3 - Lower severe disability, 4 - Upper severe disability, 5 - Lower moderate disability, 6 - Upper moderate disability, 7 - Lower good recovery, and 8 Upper good recovery [11].

\section{Discussion}

Recent evidence has proposed that the benefit of erythropoietin in traumatic brain injury is mainly due to its apoptosis-inhibiting properties since acute and delayed cell death following TBI is said to be associated with apoptotic pathways [9]. In addition, the anti-excitotoxic, antioxidant, anti-edematous, and antiinflammatory effects of EPO also help in ameliorating secondary injury effects after TBI. Moreover, EPO stimulates angiogenesis and protects the integrity of the vascular bed integrity, which may provide improvement in brain perfusion [7]. 
Citation: Garciano FB, Noble PN. The effect of post-injury erythropoietin administration on mortality and Glasgow outcome scales of patients with traumatic brain injury: A meta-analysis. J Neurol Neurorehabil Res. 2017;2(2):6-9.

Table 1: Characteristics of randomized controlled trials included in the study.

\begin{tabular}{|c|c|c|c|c|}
\hline Primary Author & Abrishamkar 2012 & Aloizos 2014 & Nichol 2015 & Robertson 2014 \\
\hline Study Title & $\begin{array}{l}\text { Effect of erythropoietin on Glasgow } \\
\text { Coma Scale and Glasgow } \\
\text { Outcome Scale in patients with } \\
\text { diffuse axonal injury }\end{array}$ & $\begin{array}{l}\text { Neuroprotective effects of } \\
\text { erythropoietin in patients with } \\
\text { severe closed brain injury }\end{array}$ & $\begin{array}{l}\text { Erythropoietin in traumatic brain } \\
\text { injury (EPO-TBI): A double-blind } \\
\text { randomised controlled trial }\end{array}$ & $\begin{array}{l}\text { Effect of erythropoietin } \\
\text { administration and transfusion } \\
\text { threshold on neurological } \\
\text { recovery after traumatic brain } \\
\text { injury: A randomized clinical trial }\end{array}$ \\
\hline Inclusion criteria & $\begin{array}{l}\text { Patients with diffuse axonal injury } \\
\text { and GCS between } 4 \text { and } 8 \text {, aged } \\
20-47 \text { years }\end{array}$ & $\begin{array}{l}\text { Patients who sustained blunt head } \\
\text { trauma with a GCS of less than } 9, \\
\text { aged }>18 \text { years }\end{array}$ & $\begin{array}{l}\text { Patients between } 15 \text { and } 65 \\
\text { years of age with non-penetrating } \\
\text { moderate (GCS 9-12) or severe } \\
\text { (GCS 3-8) TBI }\end{array}$ & $\begin{array}{l}\text { Patients with a closed head } \\
\text { injury who were not able to follow } \\
\text { commands after resuscitation }\end{array}$ \\
\hline Exclusion criteria & $\begin{array}{l}\text { Patients who had any } \\
\text { contraindication to CT scan, } \\
\text { unclear onset of clinical signs, } \\
\text { quickly resolving neurologic } \\
\text { symptoms after } 24 \text { hours, GCS < } \\
4 \text { and }>8 \text {, those who had surgery } \\
\text { within the last } 4 \text { weeks, all who had } \\
\text { SAH or ICH, brain neoplasm, or } \\
\text { severe internal medicine diseases }\end{array}$ & $\begin{array}{l}\text { Patients with penetrating trauma, } \\
\text { pregnant, those with a serious } \\
\text { premorbid disease or peripheral } \\
\text { edema, and those who had cardiac } \\
\text { arrest }\end{array}$ & $\begin{array}{l}\text { GCS of } 3 \text { and fixed dilated pupils; } \\
\text { history of deep vein thrombosis, } \\
\text { pulmonary embolism, or other } \\
\text { thromboembolic event; treatment } \\
\text { with erythropoietin in the past } 30 \\
\text { days; and the first dose of study } \\
\text { drug unable to be given within } 24 \\
\text { hours of primary injury }\end{array}$ & $\begin{array}{l}\text { GCS of } 3 \text { with fixed dilated pupils, } \\
\text { penetrating trauma, pregnancy, } \\
\text { life-threatening systemic injuries, } \\
\text { and severe pre-existing disease }\end{array}$ \\
\hline Intervention & $\begin{array}{l}\text { Erythropoietin at } 2,000 \text { units } \\
\text { subcutaneously for six doses in } \\
\text { two weeks (n=27) vs placebo } \\
(n=27)\end{array}$ & $\begin{array}{l}\text { Erythropoietin at } 10,000 \text { units for } \\
\text { seven consecutive days }(n=24) \text { vs } \\
\text { placebo }(n=18)\end{array}$ & $\begin{array}{l}\text { Erythropoietin at } 40,000 \text { units } \\
\text { subcutaneously once per week for } \\
\text { a maximum of three doses }(n=305) \\
\text { vs placebo }(n=297)\end{array}$ & $\begin{array}{l}\text { Erythropoietin at } 500 \text { units } / \mathrm{kg} \\
\text { given as either one dose within } \\
\text { six hours of injury followed by } \\
\text { two additional doses given every } \\
24 \text { hours or as single dose within } \\
\text { six hours of injury }(n=102) \text { vs } \\
\text { placebo }(n=98)\end{array}$ \\
\hline Primary outcome & $\begin{array}{l}\text { Glasgow Outcome Scale upon } \\
\text { discharge }\end{array}$ & $\begin{array}{l}\text { Glasgow Outcome Scale-Extended } \\
\text { version at } 6 \text { months post-injury }\end{array}$ & $\begin{array}{l}\text { Glasgow Outcome Scale-Extended } \\
\text { version at } 6 \text { months post-injury }\end{array}$ & $\begin{array}{l}\text { Glasgow Outcome Scale at } 6 \\
\text { months post-injury }\end{array}$ \\
\hline Secondary outcome & $\begin{array}{l}\text { Mortality, serum EPO, hematocrit, } \\
\text { hemoglobin, leukocyter and } \\
\text { thrombocyte counts, partial } \\
\text { prothrombin time, C-reactive } \\
\text { protein, ferritin, transferrin, iron, } \\
\text { electrolytes, glucose, blood urea } \\
\text { nitrogen, and creatinine }\end{array}$ & $\begin{array}{l}\text { Mortality, Glasgow Outcome Scale, } \\
\text { ARDS, infections, thromboembolic } \\
\text { events }\end{array}$ & $\begin{array}{l}\text { Mortality, proximal deep venous } \\
\text { thrombosis, composite thrombotic } \\
\text { outcome }\end{array}$ & Mortality \\
\hline Type of study & $\begin{array}{l}\text { Randomized trial using a factorial } \\
\text { design }\end{array}$ & Randomized controlled trial & $\begin{array}{l}\text { Randomized } \\
\text { controlled trial }\end{array}$ & $\begin{array}{l}\text { Randomized } \\
\text { controlled trial }\end{array}$ \\
\hline
\end{tabular}

Table 2. Summary of outcomes of the randomized controlled trials on erythropoietin versus placebo for TBI.

\begin{tabular}{|c|c|c|c|c|c|}
\hline Outcome & Number of studies & Statistical method & Effect estimate & Confidence interval & $\mathbf{I}^{2}$ \\
\hline Mortality & 4 & $\begin{array}{l}\text { Odds ratio }(\mathrm{M}-\mathrm{H}, \text { Fixed, } \\
95 \% \mathrm{Cl})\end{array}$ & 0.63 & $0.43,0.93$ & $0 \%$ \\
\hline Glasgow Outcome Scale & 3 & $\begin{array}{l}\text { Standard Mean Difference } \\
\text { (IV, Fixed } 95 \% \mathrm{Cl} \text { ) }\end{array}$ & 0.19 & $-0.07,0.45$ & $98 \%$ \\
\hline
\end{tabular}

\begin{tabular}{|c|c|c|c|c|c|c|c|c|c|}
\hline \multirow[b]{2}{*}{ Study or Subgroup } & \multicolumn{2}{|c|}{ Erythropoietin } & \multicolumn{2}{|c|}{ Placebo } & \multirow{2}{*}{ Weight } & \multirow{2}{*}{$\begin{array}{l}\text { Odds Ratio } \\
\mathrm{M}-\mathrm{H} \text {, Fixed, } 95 \% \mathrm{Cl}\end{array}$} & \multirow{2}{*}{\multicolumn{3}{|c|}{$\begin{array}{c}\text { Odds Ratio } \\
\mathrm{M}-\mathrm{H} \text {, Fixed, } 95 \% \mathrm{Cl}\end{array}$}} \\
\hline & Events & Total & Events & Total & & & & & \\
\hline Abrishamkar 2012 & 2 & 27 & 2 & 27 & $2.9 \%$ & $1.00[0.13,7.67]$ & & & \\
\hline Aloizos 2014 & 2 & 24 & 4 & 18 & $6.6 \%$ & $0.32[0.05,1.97]$ & & & \\
\hline Nichol 2015 & 32 & 305 & 46 & 297 & $65.7 \%$ & $0.64[0.39,1.04]$ & & & \\
\hline Robertson 2014 & 13 & 92 & 18 & 89 & $24.8 \%$ & $0.65[0.30,1.42]$ & & & \\
\hline Total $(95 \% \mathrm{Cl})$ & & 448 & & 431 & $100.0 \%$ & $0.63[0.43,0.93]$ & & & \\
\hline Total events & 49 & & 70 & & & & & & \\
\hline \multicolumn{7}{|c|}{$\begin{array}{l}\text { Heterogeneity: } \mathrm{Chi}^{2}=0.75, \mathrm{df}=3(P=0.86) ; \mathrm{I}^{2}=0 \% \\
\text { Test for overall effect: } Z=2.30(P=0.02)\end{array}$} & $0.01 \quad 0.1$ & $\begin{array}{cc}1 & 10 \\
\text { thropoietin Favours Placebo }\end{array}$ & 100 \\
\hline
\end{tabular}

Figure 1. Forest plot (reading) of mortality rates in erythropoietin versus placebo group.

In animal models of TBI, EPO has been known to provide neuroprotection in doses ranging from 1000 to 7000 units $/ \mathrm{kg}$, with a dose of 5000 units $/ \mathrm{kg}$ providing the best recovery of neurologic function and preservation of hippocampal neurons [7]. This study included randomized controlled trials that used EPO doses from 2,000 to 40,000 units.

Different dosing regimens for EPO have been used in animal models of TBI. However, studies have shown that a dose regimen of daily dosing for three days post-injury resulted to better recovery of function and preservation of hippocampal neurons compared to single dosing, although both treatment regimens were said to provide neuroprotection [7]. This study included randomized controlled trials, which used multiple doses following TBI. One limitation of this study is that the authors were not able to analyze at what specific erythropoietin dosing regimen is most effective for TBI.

Although this study demonstrated lower mortality rates in patients given erythropoietin following traumatic brain injury compared to placebo, there was no significant difference between the Glasgow Outcome Scales of both treatment groups. 


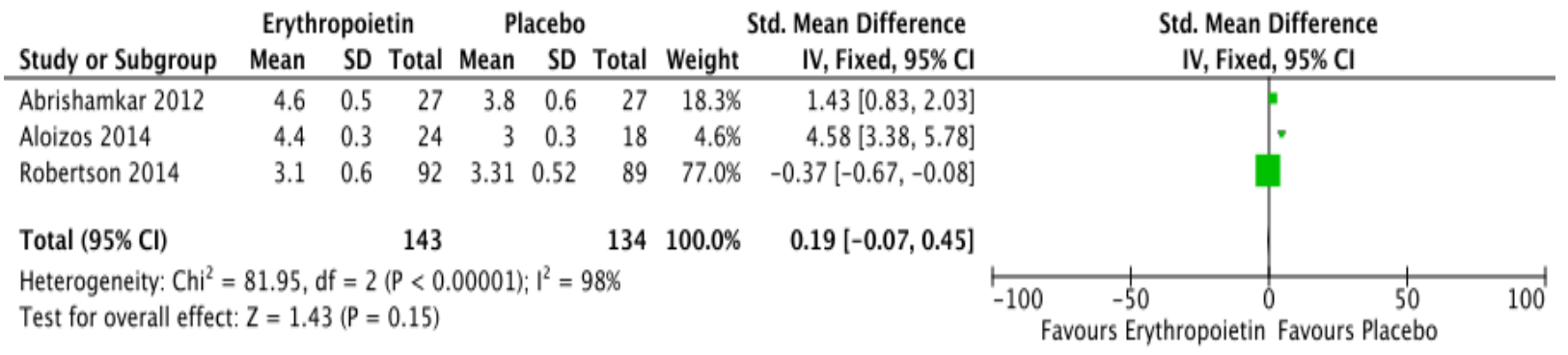

Figure 2. Forest plot (reading) of Glasgow Outcome Scales in erythropoietin versus placebo group.

This may be due to the heterogeneity of groups analyzed as shown in Figure 2. The heterogeneity may be attributed to the fact that Glasgow Outcome Scales among the different studies analyzed were not measured at the same time after trauma. The study by Abrishamkar et al. measured Glasgow Outcome Scales upon discharge of the patient from the hospital [15], while the studies of Aloizos et al., Nichol et al. and Robertson measured Glasgow Outcome Scales six months post-injury [2,14,16].

\section{Conclusion and Recommendations}

This meta-analysis has shown that post-injury treatment with erythropoietin, regardless of dose, dosing regimen, and route of administration yielded lower mortality rates in patients with traumatic brain injury but had no significant effect on Glasgow Outcome Scales.

It is recommended that further large scale randomized controlled trials be performed in order to fully establish the safety and support the efficacy of erythropoietin administration in patients with traumatic brain injury.

\section{References}

1. Menon DK, Schwab K, Write DW, et al. Position statement: Definition of traumatic brain injury. Arch Phys Med Rehab. 2010;9:1637-40.

2. Aloizos S, Evodia E, Gourgiotis S, et al. Neuroprotective effects of erythropoietin in patients with severe closed brain injury. Turk Neurosurg. 2015;25:552-8.

3. Hyder AA, Wunderlich CA, Puvanachandra P, et al. The impact of traumatic brain injuries: a global perspective. Neuro Rehabilitation. 2007;22:341-53.

4. Consunji RJ, Marinas JPES, Maddumba JRA, et al. A profile of deaths among trauma patients in a university hospital: The Philippine experience. J Inj Violence Res. 2007;3:85-9.

5. Loane DJ, Faden AI. Neuroprotection for traumatic brain injury: translational challenges and emerging therapeutic strategies. Trends Pharmacol Sci. 2010;31:596-604.

6. Kabadi SV, Faden AI. Neuroprotective strategies for traumatic brain injury: improving clinical translation. Int $\mathrm{J}$ Mol Sci. 2014;15:1216-36.

7. Ponce LL, Navarro JC, Ahmed O, et al. Erythropoietin neuroprotection with traumatic brain injury. Pathophysiology. 2013;20:31-8.

8. Talving $\mathrm{P}$, Lustenberger $\mathrm{T}$, Kobayashi $\mathrm{L}$, et al.
Erythropoiesis stimulating agent administration improves survival after severe traumatic brain injury: A matched case control study. Ann Surg. 2010; 251:1-4.

9. Mammis A, McIntosh TK, Maniker AH. Erythropoietin as a neuroprotective agent in traumatic brain injury: Review. Surg Neurol. 2009;71:527-31.

10. Peng W, Xing Z, Yang J, et al. The efficacy of erythropoietin in treating experimental traumatic brain injury: a systematic review of controlled trials in animal models. J Neurosurg. 201;121:653-64.

11. Wilson JT, Pettigrew LE, Teasdale GM. Structured interviews for the Glasgow Outcome Scale and the extended Glasgow Outcome Scale: Guidelines for their use. J Neurotrauma. 1998;15:573-85.

12. Talving $\mathrm{P}$, Lustenberger $\mathrm{T}$, Inaba $\mathrm{K}$, et al. Erythropoiesisstimulating agent administration and survival after severe traumatic brain injury. Arch Surg. 2012;147:251-5.

13. Nirula R, Diaz AR, Brasel K, et al. Safety and efficacy of erythropoietin in traumatic brain injury patients: A pilot randomized trial. Crit Care Res Pract. 2010;1-5.

14. Nichol A. Craig F, Lorraine L, et al. Erythropoietin in traumatic brain injury (EPO-TBI): A double-blind randomised controlled trial. Lancet. 2015;386:2499-506.

15. Abrishamkar S, Safavi M, Honarmand A. Effect of erythropoietin on Glasgow Coma Scale and Glasgow Outcome Scale in patient with diffuse axonal injury. J Res Med Sci. 2012;17:51-6.

16. Robertson CS, Hannay HJ, Yamal JM, et al. Effect of erythropoietin administration and transfusion threshold on neurological recovery after traumatic brain injury: A randomized clinical trial. JAMA 2014;312:36-47.

\section{*Correspondence to:}

Faye B Garciano

Department of Neurology

University of the Philippines

Philippines

Tel: +6325240534

Fax:+632524 0534

E-mail: faye_garciano@yahoo.com 